\title{
THE STUDY OF LEACHABILITY AND TOXICITY OF SLUDGE AFTER NEUTRALIZATION OF SARAKA AND ROBULE AMD WASTEWATERS
}

\author{
Vojka Gardić, ${ }^{1, \#}$, Radmila Marković1 ${ }^{1}$ Nobuyuki Masuda ${ }^{2}$, Jovica Sokolović ${ }^{3}$, \\ Jelena Petrović ${ }^{1}$, Stefan Đorđievski ${ }^{1}$, Dragana Božić ${ }^{1}$ \\ ${ }^{1}$ Mining and Metallurgy Institute Bor, Zeleni bulevar 35, 19210 Bor, Serbia \\ ${ }^{2}$ International Center for Research and Education on Mineral Engineering and \\ Resources, Akita University, 1-1 Tegata Gakuen-machi, Akita, 010-8502, Japan \\ ${ }^{3}$ University of Belgrade, Technical Faculty in Bor, Vojske Jugoslavije 12, 19210 Bor, Serbia
}

(Received: September 29, 2017; Accepted: November 24, 2017)

\begin{abstract}
Acid mine drainage (AMD) waters are one of the most important ecological risks at the global level because of its high heavy metals content and strong acidity. Treatment of AMD water is a complex and expensive. One of the most widely used treatment process is the neutralization process of AMD. The result of neutralization is the production of sludge which may contain various other (heavy) metals, depending on the chemical characteristics of the mine water treated.

In this paper, leachability and toxicity of the sludges obtained during the neutralization process of wastewater from Saraka and Robule acid mine drainage and the sludges after the stabilization process at different temperatures is tested. Sludge produced in the neutralization process of Robule AMD R4 (40) and stabilized on $105{ }^{\circ} \mathrm{C}$ and $200^{\circ} \mathrm{C}$ shows a H8-corrosiveness characteristic. Stabilized sludge show tendency to lower leachability of zinc and copper, but without influence on sulphate leachability. Sludges that show a H8-corrosiveness needs additional stabilization/neutralization pretreatment prior temperature treatment.
\end{abstract}

Key words: sludge; neutralization; heavy metals; leachability; TCLP.

\section{Introduction}

Mining and processing of metal ores cause degradation and pollution of land due to deposition of large mining wastes (overburden and flotation tailings) as well as AMD formation.

Hundreds of hectares of land and thousands of kilometers of rivers and springs all over the world are endangered by circulation of AMD [1]. It is characterized by low $\mathrm{pH}$ value and high concentrations of potentially toxic dissolved metals, metalloids and sulphate [2-7].
The formation of AMD water is caused by uncontrolled oxidation of sulphide minerals, especially pyrite $\left(\mathrm{FeS}_{2}\right)$, resulting from the exposure of these minerals to oxygen, water and microorganisms [8-14], as a consequence of the mining and processing of metal ores and coals [1]. The mechanism of acid mine drainage (AMD) water formation was the subject of intensive research during last twenty years. Forming of AMD water from pyrite ore $\left(\mathrm{FeS}_{2}\right)$ is usually described by the following reactions $[4,10,15-21]$ :

\#Corresponding author:vojka.gardic@irmbor.co.rs

*A part of this study was presented at the XII International Symposium on Recycling Technologies and Sustainable Development (XII RTSD), organized by University of Belgrade, Technical faculty in Bor, from $13^{\text {th }}$ to $15^{\text {th }}$ September 2017, Hotel Jezero, Bor Lake, Serbia. 


$$
\begin{aligned}
& \mathrm{FeS}_{2}+7 / 2 \mathrm{O}_{2}+\mathrm{H}_{2} \mathrm{O} \rightarrow \mathrm{Fe}^{2+}+2 \mathrm{SO}_{4}{ }^{2-}+2 \mathrm{H}^{+} \\
& \mathrm{Fe}^{2+}+1 / 4 \mathrm{O}_{2}+\mathrm{H}^{+} \rightarrow \mathrm{Fe}^{3+}+1 / 2 \mathrm{H}_{2} \mathrm{O} \\
& \mathrm{Fe}^{3+}+3 \mathrm{H}_{2} \mathrm{O} \rightarrow \mathrm{Fe}(\mathrm{OH})_{3}+3 \mathrm{H}^{+} \\
& \mathrm{FeS}_{2}+15 / 2 \mathrm{O}_{2}+7 / 2 \mathrm{H}_{2} \mathrm{O} \rightarrow \mathrm{Fe}(\mathrm{OH})_{3}+2 \mathrm{SO}_{4}{ }^{2-}+4 \mathrm{H}^{+} \\
& \mathrm{FeS}_{2}+14 \mathrm{Fe}^{3+}+8 \mathrm{H}_{2} \mathrm{O} \rightarrow 15 \mathrm{Fe}^{2+}+2 \mathrm{SO}_{4}{ }^{2-}+16 \mathrm{H}^{+} \\
& \mathrm{FeS}_{2}+15 / 4 \mathrm{O}_{2}+1 / 2 \mathrm{H}_{2} \mathrm{O} \rightarrow \mathrm{Fe}^{3+}+2 \mathrm{SO}_{4}{ }^{2-}+\mathrm{H}^{+}
\end{aligned}
$$

The oxidation of the pyrite (or sulphide) into dissolved iron, sulphate and hydrogen is the first and most important reaction (Eq. (1)) [15]. Also, the presence of sulphate is typically the first indicator of sulphide mineral oxidation [17].

The overall reaction of pyrite oxidation (eq. (1)-(3)) is represented by equation 4 . Equation 5 shows complete oxidation of pyrite where ferric acts as the oxidizing agent, and is also deemed a faster reaction than reaction [12]. As can be seen from reaction (5), the oxidation of pyrite by ferric iron results in a further decrease in $\mathrm{pH}$ [20]. However, the rate of pyrite oxidation and the resulting acid production depend on various variables such as: composite solid phase composition and microbial activity, as well as the availability of oxygen and water [17].

The complete oxidation of pyrite in the presence of low water content is represented by reaction (6) [21]. It must be noted that reactions (2) and (4) can be significantly accelerated by the presence of acidophilus bacteria, such as Thiobacillus ferroxidans [17, 20]. It has been shown that these bacteria increase the iron conversion rate factor from hundreds to a million times [20, 22].

Acid mine drainage, as one of the major environmental pollution problems, is associated with historic and current mining industries [1, 23]. It causes problems to current and future generations because of its high heavy metal content and strong acidity [24]. The type and metals concentration present at mine drainage depends on nature of ore deposits.
Copper mines are mostly responsible for acid water forming. Uncontrolled drainage or pumping out of such water into nearest water streams pollutes living environment in large scale. At some copper mines, AMD is detected after $2-5$ years from the beginning of mining operations. Abandoned copper mines and tailing dumps can generate acid water for tens, hundreds and even thousand of years [16]. One of examples of such pollution is abandoned pyrite mine Richmond in California (USA) for which one it is estimated that it can generate extremely acid solutions for the next 3000 years. For a small zinc and copper mine at north-west Ontario (Canada) it is estimated that it will create AMD waters for $10000-35000$ years [16]. Although these two examples are extreme, it is not unusual that abandoned mines and tailing dumps have a capacity of generating acid solutions for hundreds of years. It is supposed that ten thousand of active or abandoned mines exist in Europe from where $5-10 \times 10^{9} \mathrm{~m}^{3}$ of polluted mine water is discharged [16]. The data scale of the world problem of AMD is argumented by the fact that more than half of mines within European Union has been closed up to now and almost all of them are metals and coal mines.

Acid mine drainage contains heavy metals such as: $\mathrm{Cu}, \mathrm{Cd}, \mathrm{Co}, \mathrm{Cr}, \mathrm{Mn}, \mathrm{Ni}, \mathrm{Pb}$ and $\mathrm{Zn}$, which have the potential to become major contamination sources, particularly in soil, and water resources [25-26]. AMD with these characteristics has not been discharged into public streams. Once AMD is generated, it is difficult to control the process and the treatment also requires high cost [1]. 
Many traditional processes for the treatment of acid mine water was briefly discussed by Kefeni et al. (2017). There may be divided into active and passive treatment options.

Among the conventional active chemical treatment options, the neutralization of AMD using various neutralizing reagents such as calcium hydroxide $\left(\mathrm{CA}(\mathrm{OH})_{2}\right)$ or limestone $\left(\mathrm{CaCO}_{3}\right)$ is a common method that has been widely applied for the removal of metals as metal hydroxide precipitates and sulphate as gypsum $\left(\mathrm{CaSO}_{4} \cdot 2 \mathrm{H}_{2} \mathrm{O}\right)$ sludge $[27,28]$.The result is the production of an iron-rich sludge that may also contain various other metals, depending on the chemistry of the mine water treated. The sludge produced by this process is voluminous, with low solid content [29], low chemical stability [30] and has no economical value and that require further treatment or disposal $[17,31]$.

The disposed sludge produced in the neutralization process of AMD presents the potential risks to human health and the environment, particularly in the area there is the possibility of occurrence acid rain. Toxic element present in neutralization sludge, $\mathrm{Zn}$, $\mathrm{Cd}, \mathrm{Pb}, \mathrm{Cu}, \mathrm{As}, \mathrm{Sb}$ and etc., can become mobile and polluted surrounding environment [32]. The sludge should be characterized in term of leachability test (mobility test of heavy metals contents in sludge). But, sludge disposal in line ponds is costly due to the following: large masses of sludge are produced. An estimated amount of $20 \mathrm{t} /$ day of sludge is produced from $1 \mathrm{M} 1 /$ day of discard leachate when neutralized with lime or limestone; plastic lining of sludge pond. Sludge produced from acid mine water is classified as a class 3 waste due to its metal content and must be discharged into a lined pond [33].

In the different European countries, tests have developed to characterize the constituents which can be leached from waste materials. The release of soluble constituents upon contact with water is regarded as a main mechanism of release in potential risk to the environment, especially during the reuse or disposal of waste materials. The intent of these tests is to identify and determine the leaching properties of waste materials. Due to the complexity of the leaching process in environmental conditions, it is necessary to simplify for laboratory research [34].

Toxicity Characteristic Leaching Procedure (TCLP) developed in USA in term of determining if a waste is hazardous or nonhazardous for disposal purposes. Also, the TCLP is used for legal waste classification. The TCLP test was designed to test toxicity characteristics by simulating leaching in an acidic landfill environment [35]. The TCLP is the current protocol required by Serbian low to characterize a waste for disposal purposes [36].

\section{Experimental}

\subsection{Materials and methods}

\subsubsection{Study site}

The Bor mining area is one of the important copper-producing areas in Serbia. The ore deposits in the mining area are porphyry copper deposits. The copper mine Bor, within the operation scope of Mining \& Smelting Basin (RTB) Bor, started mining operations in the year 1903. For more than one hundred years of mining, about 673.5 million tons of overburden and flotation tailings were deposited in and near the municiplity of Bor [37-40]. Also, over 29,000 hectares of land it has been by quality strongly degraded. The area of such agricultural degraded land from the total percentage of agricultural land of the Bor District amounts over $60 \%$ [40]. 
The area of Copper mine Bor represents a classical example of land degradation due to mining and processing of copper ore and disposing of mining wastes and flotation tailings. During the decades of exploitation of ore from the open pit Bor at different locations ("Visoki Planir" - also called "Oštreljski planir", "Severni planir" dump of ore body "H" (RTH)) mine overburden and tailings were delayed [40].

Active mine and flotation tailing dumps and industrial operations of RTB Bor create large amounts of acid mine water polluting natural rivers and springs with approximately $1285 \mathrm{t}$ of Fe, $500 \mathrm{t}$ of $\mathrm{Cu}, 52 \mathrm{t}$ of $\mathrm{Zn}, 62 \mathrm{t}$ of $\mathrm{Mn}, 1.8 \mathrm{t}$ of $\mathrm{Pb}, 1.3 \mathrm{t}$ of $\mathrm{Ni}, 400 \mathrm{~kg}$ of As and about $250 \mathrm{~kg}$ of $\mathrm{Cd}$ [41]. This water flows into the Robule lake and the Bor River and Krivelj River, which further flow into the Timok River and Danube River.

The Robule lake (figure 1) located close to the Bor city is characterized by low $\mathrm{pH}$ value and high concentration of metals [40]. It was built during 1970s as a consequence of the depositing of the large amount of overburden, about 150 million tons, that formed Veliki Planir. As a result of weathering, the products of oxidation are dissolved and leached in the form of AMD wastewaters, whose influence on the environment is extremely harmful due to a high content of heavy metal ions and sulphuric acid [37].

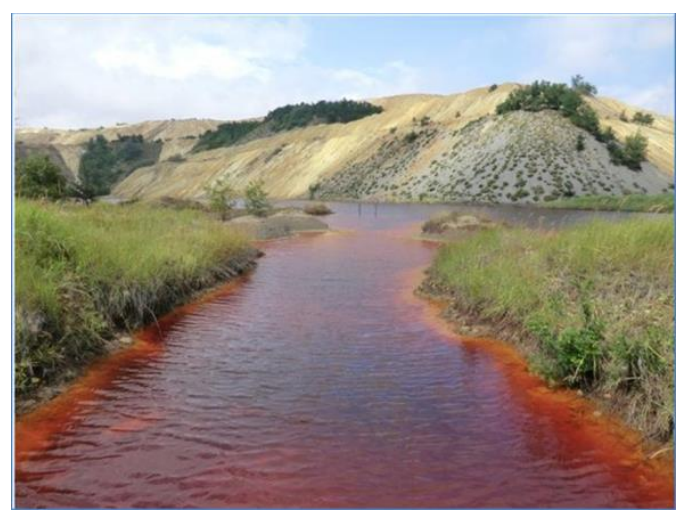

Figure 1. Robule lake
The ore exploitation at open pit mine Veliki Krivelj started in 1983. Since then, south of the open pit Veliki Krivelj, in the valley of the Saraka stream (figure 2), is situated a landfill for disposing of overburden. Since 1998, when the transportation system was built, overburden from the mine Veliki Krivelj is transported to the old open pit of Bor.

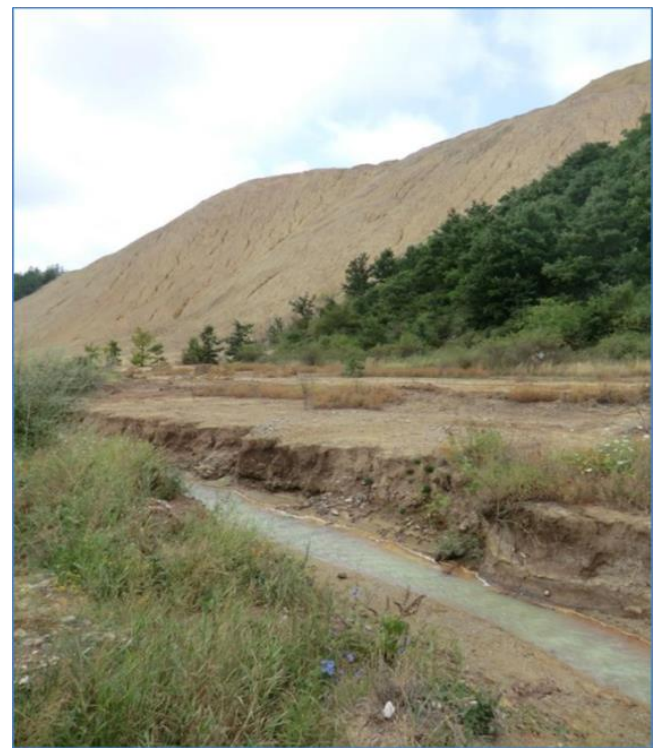

Figure 2. Saraka stream

Several thousands of cubic meters of $\mathrm{AMD}$, as a consequence of the weathering from mine dumps, flows into the Borska and Kriveljska river every day [42]. Accordingly, both the Borska and the Kriveljska river are open collectors of acid mine drainage. Besides polluting the living environment, free discharge of acid waste water containing remarkable amount of various metals is a rather important economic loss [4].

The aims of this study are to determine the characteristics of the AMD from the Robule lake and Saraka stream and testing the leachability of sludges obtained during the neutralization process of these AMD and sludges after the stabilization process on different stabilization temperature. 


\subsubsection{Materials}

The study was carried out in the region of the Bor mining area. Water samples were taken periodically from the Robule lake and Saraka stream.
Water sampling locations are shown in Figure 3 and are given by the following labels:

P-1 Robule lake (Figure 1);

P-2 Saraka stream (Figure 2).

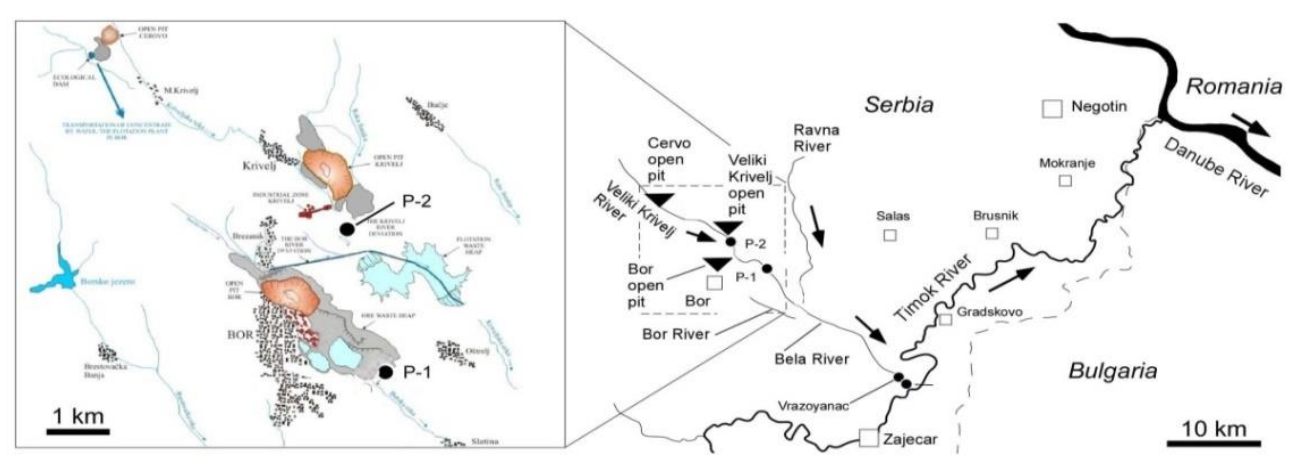

Figure 3. Map of the sampling locations in the area of the cities of Bor and Zaječar

As shown in Fig. 3, both samples were collected around the Bor mine and were then filtered through the $0.45 \mu \mathrm{m}$ membrane to remove any debris or suspended solids. The samples were stored in closed high-density polyethylene bottles and kept at $4{ }^{\circ} \mathrm{C}$ [43].
All of the chemical reagents used were analytical reagent (AR) grade chemicals.

The characteristics of the AMD from the Robule lake and Saraka stream are presented in Table 1, which shows the mean values for all the water samples.

Table 1. Characteristic of AMD water samples

\begin{tabular}{|c|c|c|c|}
\hline \multirow{2}{*}{ Parameter } & \multirow{2}{*}{ Measure unit } & \multicolumn{3}{|c|}{ Mark of water samples } \\
\cline { 3 - 4 } & & P-1 & P-2 \\
\hline $\mathrm{pH}$ & - & 2.7 & 4.3 \\
\hline $\mathrm{Al}$ & $\mathrm{mg} / \mathrm{l}$ & 330.8 & 71.005 \\
\hline $\mathrm{Cu}$ & $\mathrm{mg} / \mathrm{l}$ & 64.4 & 75.112 \\
\hline $\mathrm{Fe}$ & $\mathrm{mg} / \mathrm{l}$ & 554.5 & 0.263 \\
\hline $\mathrm{Mn}$ & $\mathrm{mg} / \mathrm{l}$ & 122.6 & 16.769 \\
\hline $\mathrm{S}$ & $\mathrm{mg} / \mathrm{l}$ & 3843.2 & 936.707 \\
\hline $\mathrm{Zn}$ & $\mathrm{mg} / \mathrm{l}$ & 26.5 & 3.5 \\
\hline $\mathrm{Ca}$ & $\mathrm{mg} / \mathrm{l}$ & 590.4 & 529.715 \\
\hline $\mathrm{Mg}$ & $\mathrm{mg} / \mathrm{l}$ & 1478.7 & 226.173 \\
\hline $\mathrm{Cr}$ & $\mu \mathrm{g} / \mathrm{L}$ & $<1.7$ & 1121.1 \\
\hline $\mathrm{Co}$ & $\mu \mathrm{g} / \mathrm{L}$ & 1354.4 & 280.1 \\
\hline $\mathrm{Ni}$ & $\mu \mathrm{g} / \mathrm{L}$ & 643.4 & 3.3 \\
\hline $\mathrm{As}$ & $\mu \mathrm{g} / \mathrm{L}$ & 6.9 & 27 \\
\hline $\mathrm{Se}$ & $\mu \mathrm{g} / \mathrm{L}$ & 17.8 & 1143.7 \\
\hline $\mathrm{Sr}$ & $\mu \mathrm{g} / \mathrm{L}$ & 1074.6 & 21.6 \\
\hline $\mathrm{Cd}$ & $\mu \mathrm{g} / \mathrm{L}$ & 73.1 & 0.10 \\
\hline $\mathrm{Cs}$ & $\mu \mathrm{g} / \mathrm{L}$ & $<0.5$ & 0.2 \\
\hline $\mathrm{Pb}$ & $\mu \mathrm{g} / \mathrm{L}$ & $<2.1$ & \\
\hline
\end{tabular}


Mass absorption method with coupled plasma (ICP-MS) on apparatus AGILEND 7700 was used for chemical analysis of: As, $\mathrm{Cd}, \mathrm{Co}, \mathrm{Cr}, \mathrm{Cs}, \mathrm{Ni}, \mathrm{Pb}, \mathrm{Sr}, \mathrm{Se}$

Atomic absorption method with inductive coupled plasma (ICP-AES) on apparatus SPECTRO BLUE was used for chemical analysis of: $\mathrm{Al}, \mathrm{Ca}, \mathrm{Cu}, \mathrm{Fe}, \mathrm{Mg}, \mathrm{Mn}, \mathrm{S}$ and $\mathrm{Zn}$.

From table 1 it can be seen that the major metal contaminant was Fe, and others, such as $\mathrm{Cu}, \mathrm{Zn}$, and $\mathrm{Mn}$ were also present.

\subsubsection{Methods}

Sludge obtained during neutralization process of Saraka AMD on $\mathrm{pH} 7$ and $\mathrm{pH} 11$ and sludge obtained during neutralization process of Robule AMD on $\mathrm{pH} 4$ and $\mathrm{pH} 8$ are testing by leachability test and toxicity characteristic test in first phase of waste characterization.

Sludges after neutralization were treated on different temperatures of stabilization and also are testing by leachability test and toxicity characteristic test in second phase of waste characterization. Mark of tested sludges are given in Table 2.

Content of $\mathrm{Zn}$ and $\mathrm{Cu}$ were determined by atomic emission spectrometry method with Induction Coupled Plasma (ICP-AES) on apparatus Ciros Vision and content of $\mathrm{Cr}$, Co, $\mathrm{Ni}, \mathrm{As}, \mathrm{Se}, \mathrm{Cd}, \mathrm{Cs}$ and $\mathrm{Pb}$ was determined by mass spectrometry method with Induction Coupled Plasma (ICP-MS) on apparatus AGILEND 7700.

Table 2. Mark of sludge samples

\begin{tabular}{|l|c|}
\hline \multicolumn{1}{|c|}{ Sludge description } & Mark of sample \\
\hline $\begin{array}{l}\text { Sludge after neutralization process of Robule AMD wastewaters up to pH } 4 \text { (dry } \\
\text { on } 40{ }^{\circ} \mathrm{C} \text { ) }\end{array}$ & R4 (40) \\
\hline $\begin{array}{l}\text { Sludge after neutralization process of Robule AMD wastewaters from pH } 4 \text { up } \\
\text { to pH } 8 \text { (dry on } 40^{\circ} \mathrm{C} \text { ) }\end{array}$ & R8 (40) \\
\hline $\begin{array}{l}\text { Sludge after neutralization process of Saraka AMD wastewaters up to pH 7 (dry } \\
\left.\text { on } 40{ }^{\circ} \mathrm{C}\right)\end{array}$ & $\mathrm{S} 7(40)$ \\
\hline $\begin{array}{l}\text { Sludge after neutralization process of Saraka AMD wastewaters from pH 7 up } \\
\left.\text { to pH } 11 \text { (dry on } 40^{\circ} \mathrm{C}\right)\end{array}$ & S11 (40) \\
\hline $\begin{array}{l}\text { Sludge after neutralization process of Robule AMD wastewaters up to pH } 4 \text { and } \\
\text { stabilization on } 105^{\circ} \mathrm{C}\end{array}$ & Rs4 (100) \\
\hline $\begin{array}{l}\text { Sludge after neutralization process of Robule AMD wastewaters from pH } 4 \text { up } \\
\text { to pH } 8 \text { and stabilization on } 105{ }^{\circ} \mathrm{C}\end{array}$ & Rs8 (100) \\
\hline $\begin{array}{l}\text { Sludge after neutralization process of Robule AMD wastewaters up to pH } 4 \text { and } \\
\text { stabilization on } 200^{\circ} \mathrm{C}\end{array}$ & Rs4 (200) \\
\hline $\begin{array}{l}\text { Sludge after neutralization process of Robule AMD wastewaters from pH } 4 \text { up } \\
\text { to pH } 8 \text { and stabilization on } 200^{\circ} \mathrm{C}\end{array}$ & Rs8 (200) \\
\hline
\end{tabular}

The impact of sludges obtained in neutralization process of AMD and sludges after stabilization process on the environment were carried out by leaching test according to standard methods EN 12457-2 (Characterization of waste - Leaching Compliance test for leaching of granular waste materials and sludge - Part 2: One stage batch test at a liquid-solid ratio of $101 / \mathrm{kg}$ for materials with a high content solids and particle size of less than $4 \mathrm{~mm}$ (with decreasing particle size, or without decreasing.

The investigated materials which originally have at least $95 \%$ mass ratio of particles below $4 \mathrm{~mm}$, brought into contact with 
leachant (water) under defined conditions. The Standard is based on the assumption that equilibrium or near-equilibrium is achieved between the liquid and solid phases during the test duration. The solid residue of eluate is separated by filtering. After the test, the leaching conditions in term of $\mathrm{pH}$, conductivity (optionally redox potential) dictated by the waste are measured) [34].

Toxicity characteristic of sludges obtained in neutralization process of AMD and sludges after stabilization process were carried out by TCLP test according to standard methods EPA 1311 (Toxicity Characteristic Leaching Procedure).

The solid phase is extracted with an amount of extraction fluid equal to 20 times the weight of the solid phase. The extraction fluid employed is a function of the alkalinity of the solid phase of the waste.
Following extraction, the liquid extract is separated from the solid phase by filtration through a $0.45 \mu \mathrm{m}$ glass fiber filter [35].

The results of waste testing are compared with limits given in Annex 10 of the Regulation on categories, testing and classification of waste (Office Gazette RS 56/2010. [36].

\section{Results and discussion}

To predicted amount/concentration of pollutant that can be released in environmental, leachability test (mobility test of heavy metals contents in sludge) is performed in Mining and Metallurgy Institute laboratories. Results of these tests are shown in Table 3 (sludges after neutralization process) and Table 4 (stabilized sludges).

Table 3. The results of the sludges characterization by leaching standard test method EN 12457-2 [4]

\begin{tabular}{|c|c|c|c|c|c|c|c|}
\hline \multirow[b]{2}{*}{ Parameter } & \multirow[b]{2}{*}{$\begin{array}{c}\text { Measure } \\
\text { unit }\end{array}$} & \multicolumn{4}{|c|}{ Content } & \multirow{2}{*}{$\begin{array}{l}\text { Limit } \\
\text { value } \\
{[36] * *}\end{array}$} & \multirow{2}{*}{$\begin{array}{l}\text { Analytical } \\
\text { testing } \\
\text { standard } \\
\text { method }\end{array}$} \\
\hline & & $\begin{array}{l}\mathrm{R} 4 \\
(40)\end{array}$ & $\begin{array}{l}\mathrm{R} 8 \\
(40)\end{array}$ & $\begin{array}{l}\text { S7 } \\
(40)\end{array}$ & $\begin{array}{l}\text { S11 } \\
(40)\end{array}$ & & \\
\hline $\mathrm{pH}$ of eluate & - & 4.31 & 8.14 & 8.11 & 9.27 & $6-13$ & $\begin{array}{c}\text { SRPS EN } \\
12506: 2007\end{array}$ \\
\hline $\begin{array}{l}\text { Conductivity of } \\
\text { eluate }\end{array}$ & $\mu \mathrm{S} / \mathrm{cm}$ & 3427 & 3293 & 1925 & 3530 & - & $\begin{array}{c}\text { SRPS EN } \\
13370: 2003\end{array}$ \\
\hline Lead, $\mathrm{Pb}$ & $\mathrm{mg} / \mathrm{kg} \mathrm{dm*}$ & 0.23 & $<0.20$ & $<0.20$ & $<0.20$ & 10 & EN ISO11885 \\
\hline Cadmium, $\mathrm{Cd}$ & $\mathrm{mg} / \mathrm{kg} \mathrm{dm} *$ & 0.24 & $<0.08$ & $<0.08$ & $<0.08$ & 1 & EN ISO11885 \\
\hline Zinc, Zn & $\mathrm{mg} / \mathrm{kg} \mathrm{dm} *$ & 146 & 0.07 & 0.49 & $<0.05$ & 50 & EN ISO11885 \\
\hline Copper, $\mathrm{Cu}$ & $\mathrm{mg} / \mathrm{kg} \mathrm{dm} *$ & 797 & 0.10 & 12 & $<0.05$ & 50 & EN ISO11885 \\
\hline Nickel, Ni & $\mathrm{mg} / \mathrm{kg} \mathrm{dm} *$ & 3.6 & $<0.07$ & $<0.07$ & $<0.07$ & 10 & EN ISO11885 \\
\hline Chromium total, $\mathrm{Cr}_{\text {tot }}$ & $\mathrm{mg} / \mathrm{kg} \mathrm{dm}{ }^{*}$ & $<0.05$ & $<0.05$ & $<0.05$ & $<0.05$ & 10 & EN ISO11885 \\
\hline Mercury, $\mathrm{Hg}$ & $\mathrm{mg} / \mathrm{kg} \mathrm{dm} *$ & $<0.05$ & $<0.05$ & $<0.05$ & $<0.05$ & 0.2 & VMK C.h.1 \\
\hline Arsenic, As & $\mathrm{mg} / \mathrm{kg} \mathrm{dm} *$ & $<0.20$ & $<0.20$ & $<0.20$ & $<0.20$ & 2 & EN ISO11885 \\
\hline Antimony, $\mathrm{Sb}$ & $\mathrm{mg} / \mathrm{kg} \mathrm{dm}{ }^{*}$ & $<0.5$ & $<0.5$ & $<0.5$ & $<0.5$ & 0.7 & VMK C.G.1 \\
\hline Barium, Ba & $\mathrm{mg} / \mathrm{kg} \mathrm{dm} *$ & 0.46 & $<0.09$ & 0.11 & $<0.09$ & 100 & EN ISO11885 \\
\hline Selenium, $\mathrm{Se}$ & $\mathrm{mg} / \mathrm{kg} \mathrm{dm} *$ & $<0.33$ & $<0.33$ & $<0.33$ & $<0.33$ & 0.5 & EN ISO11885 \\
\hline Molibdenium, Mo & $\mathrm{mg} / \mathrm{kg} \mathrm{dm} *$ & $<0.07$ & $<0.07$ & $<0.07$ & $<0.07$ & 10 & EN ISO11885 \\
\hline Chloride $\left(\mathrm{Cl}^{-}\right)$ & $\mathrm{mg} / \mathrm{kg} \mathrm{dm} *$ & 6 & 7 & 18 & 16 & 15000 & $\begin{array}{c}\text { SRPS EN } \\
12506: 2007\end{array}$ \\
\hline Sulphate $\left(\mathrm{SO}_{4}{ }^{2-}\right)$ & $\mathrm{mg} / \mathrm{kg} \mathrm{dm*}$ & 28000 & 23500 & 21000 & 24500 & 20000 & $\begin{array}{c}\text { SRPS EN } \\
12506: 2007\end{array}$ \\
\hline
\end{tabular}


Table 4. The results of stabilized sludges on $105{ }^{\circ} \mathrm{C}$ and $200{ }^{\circ} \mathrm{C}$ characterization by leaching standard test method EN 12457-2 [4]

\begin{tabular}{|c|c|c|c|c|c|c|c|}
\hline \multirow[b]{2}{*}{ Parameter } & \multirow[b]{2}{*}{$\begin{array}{l}\text { Measure } \\
\text { unit }\end{array}$} & \multicolumn{4}{|c|}{ Content } & \multirow{2}{*}{$\begin{array}{c}\text { Limit } \\
\text { value } \\
{[36] * *}\end{array}$} & \multirow{2}{*}{$\begin{array}{c}\text { Analytical } \\
\text { testing } \\
\text { standard } \\
\text { method }\end{array}$} \\
\hline & & $\begin{array}{c}\mathrm{R} 4 \\
(105)\end{array}$ & $\begin{array}{c}\mathrm{R} 8 \\
(105)\end{array}$ & $\begin{array}{c}\mathrm{R} 4 \\
(200)\end{array}$ & $\begin{array}{c}\mathrm{R} 8 \\
(200)\end{array}$ & & \\
\hline $\mathrm{pH}$ of eluate & - & 4.44 & 7.91 & 4.50 & 8.37 & $6-13$ & $\begin{array}{c}\text { SRPS EN } \\
12506: 2007\end{array}$ \\
\hline $\begin{array}{l}\text { Conductivity of } \\
\text { eluate }\end{array}$ & $\mu \mathrm{S} / \mathrm{cm}$ & 3313 & 2803 & 2623 & 3128 & - & $\begin{array}{c}\text { SRPS EN } \\
\text { 13370:2003 }\end{array}$ \\
\hline Lead, $\mathrm{Pb}$ & $\mathrm{mg} / \mathrm{kg} \mathrm{dm} *$ & 0.68 & $<0.20$ & $<0.20$ & $<0.20$ & 10 & EN ISO11885 \\
\hline Cadmium, $\mathrm{Cd}$ & $\mathrm{mg} / \mathrm{kg} \mathrm{dm} *$ & 0.09 & $<0.08$ & 0.11 & $<0.08$ & 1 & EN ISO11885 \\
\hline Zinc, $\mathrm{Zn}$ & $\mathrm{mg} / \mathrm{kg} \mathrm{dm} *$ & 127 & $<0.05$ & 39 & 0.68 & 50 & EN ISO11885 \\
\hline Copper, $\mathrm{Cu}$ & $\mathrm{mg} / \mathrm{kg} \mathrm{dm} *$ & 828 & $<0.05$ & 287 & 1.3 & 50 & EN ISO11885 \\
\hline Nickel, Ni & $\mathrm{mg} / \mathrm{kg} \mathrm{dm*}$ & 2.2 & $<0.07$ & 0.7 & $<0.07$ & 10 & EN ISO11885 \\
\hline Chromium total, $\mathrm{Cr}_{\text {tot }}$ & $\mathrm{mg} / \mathrm{kg} \mathrm{dm} *$ & $<0.05$ & $<0.05$ & $<0.05$ & $<0.05$ & 10 & EN ISO11885 \\
\hline Mercury, $\mathrm{Hg}$ & $\mathrm{mg} / \mathrm{kg} \mathrm{dm} *$ & $<0.05$ & $<0.05$ & $<0.05$ & $<0.05$ & 0.2 & VMK C.h.1 \\
\hline Arsenic, As & $\mathrm{mg} / \mathrm{kg} \mathrm{dm*}$ & $<0.20$ & $<0.20$ & $<0.20$ & $<0.20$ & 2 & EN ISO11885 \\
\hline Antimony, $\mathrm{Sb}$ & $\mathrm{mg} / \mathrm{kg} \mathrm{dm} *$ & $<0.5$ & $<0.5$ & $<0.5$ & $<0.5$ & 0.7 & VMK C.G.1 \\
\hline Barium, $\mathrm{Ba}$ & $\mathrm{mg} / \mathrm{kg} \mathrm{dm} *$ & 0.22 & 0.10 & 0.31 & $<0.09$ & 100 & EN ISO11885 \\
\hline Selenium, Se & $\mathrm{mg} / \mathrm{kg} \mathrm{dm} *$ & $<0.33$ & $<0.33$ & $<0.33$ & $<0.33$ & 0.5 & EN ISO11885 \\
\hline Molibdenium, Mo & $\mathrm{mg} / \mathrm{kg} \mathrm{dm} *$ & $<0.07$ & $<0.07$ & $<0.07$ & $<0.07$ & 10 & EN ISO11885 \\
\hline Chloride $\left(\mathrm{Cl}^{-}\right)$ & $\mathrm{mg} / \mathrm{kg} \mathrm{dm*}$ & 5 & 7 & 6 & 7 & 15000 & $\begin{array}{c}\text { SRPS EN } \\
12506: 2007\end{array}$ \\
\hline Sulphate $\left(\mathrm{SO}_{4}{ }^{2-}\right)$ & $\mathrm{mg} / \mathrm{kg} \mathrm{dm*}$ & 28500 & 21500 & 21000 & 26000 & 20000 & $\begin{array}{c}\text { SRPS EN } \\
12506: 2007\end{array}$ \\
\hline
\end{tabular}

*dm - dry mass

Sludge obtained in the neutralization process of Robule AMD R4 (40) and sludges stabilized on $105{ }^{\circ} \mathrm{C}$ and $200{ }^{\circ} \mathrm{C}$ shows a H8corrosiveness characteristic, because of eluate $\mathrm{pH}$ values significantly lower $(4.31,4.44$ and 4.50 , respectly) than the limit value (6.0) and indicates the acidity eluate generated during the leaching test. Also, content of sulphate is higher than limit for unhazardous waste for all tested sludge samples.

Sludge produced in the neutralization process of Robule AMD R4 (40) and stabilized on $105^{\circ} \mathrm{C}$ shows higher leachability of zinc and copper than limit values. Sludge produced in the neutralization process of Robule AMD and stabilized on $200{ }^{\circ} \mathrm{C}$ shows higher leachability only for copper.
Sludge produced in the neutralization process of Saraka AMD S7 and S11 are in accordance with applicable laws and regulations of the Republic of Serbia, except of sulphate content.

To predicted amount/concentration of pollutant that can be released in environmental, leaching in an acidic landfill environment (toxicity characteristic of sludges) is performed in Mining and Metallurgy Institute laboratories especially on samples that not shows hazardous characteristic by leachability test.

The result of these tests is shown in Table 5 (sludge after neutralization process) and Table 6 (stabilized sludge). 
Table 5. The results of toxicity characteristic of sludge by TCLP test method

\begin{tabular}{|c|c|c|c|c|c|c|}
\hline \multirow[b]{2}{*}{ Parameter } & \multirow[b]{2}{*}{$\begin{array}{c}\text { Measure } \\
\text { unit }\end{array}$} & \multicolumn{3}{|c|}{ Content } & \multirow[b]{2}{*}{$\begin{array}{c}\text { Limit } \\
\text { value[36] }\end{array}$} & \multirow{2}{*}{$\begin{array}{c}\text { Analytical } \\
\text { testing } \\
\text { standard } \\
\text { method }\end{array}$} \\
\hline & & R8 (40) & S7 (40) & S11 (40) & & \\
\hline Lead, $\mathrm{Pb}$ & $\mu \mathrm{g} / \mathrm{L}$ & $<2.1$ & $<2.1$ & $<2.1$ & 5000 & EN ISO11885 \\
\hline Cadmium, $\mathrm{Cd}$ & $\mu \mathrm{g} / \mathrm{L}$ & 284.8 & 53.9 & 0.19 & 1000 & EN ISO11885 \\
\hline Zinc, Zn & $\mathrm{mg} / \mathrm{L}$ & 24.9 & 1.8 & 0.009 & 250 & EN ISO11885 \\
\hline Copper, $\mathrm{Cu}$ & $\mathrm{mg} / \mathrm{L}$ & 5.8 & 2.9 & 0.080 & 25 & EN ISO11885 \\
\hline Nickel, Ni & $\mathrm{mg} / \mathrm{L}$ & 2.0 & 0.20 & $<0.007$ & 20 & EN ISO11885 \\
\hline $\begin{array}{l}\text { Chromium total, } \\
\mathrm{Cr}_{\text {tot }}\end{array}$ & $\mu \mathrm{g} / \mathrm{L}$ & 1.9 & $<1.7$ & 20.0 & 5000 & EN ISO11885 \\
\hline Mercury, $\mathrm{Hg}$ & $\mathrm{mg} / \mathrm{L}$ & $<0.0005$ & $<0.0005$ & $<0.0005$ & 0.2 & VMK C.h.1 \\
\hline Arsenic, As & $\mu \mathrm{g} / \mathrm{L}$ & $<2.1$ & $<2.1$ & 4.1 & 5000 & EN ISO11885 \\
\hline Antimony, $\mathrm{Sb}$ & $\mu \mathrm{g} / \mathrm{L}$ & $<0.86$ & $<0.86$ & 10.4 & 15000 & VMK C.G.1 \\
\hline Barium, $\mathrm{Ba}$ & $\mu \mathrm{g} / \mathrm{L}$ & 32.5 & 38.4 & 6.8 & 100000 & EN ISO11885 \\
\hline Selenium, $\mathrm{Se}$ & $\mu \mathrm{g} / \mathrm{L}$ & $<4.5$ & 9.7 & 21.0 & 1000 & EN ISO11885 \\
\hline Molibdenium, Mo & $\mathrm{mg} / \mathrm{L}$ & $<0.0023$ & 0.0239 & 0.0101 & 350 & EN ISO11885 \\
\hline Vanadium, V & $\mathrm{mg} / \mathrm{L}$ & $<0.008$ & 0.048 & $<0.008$ & 24 & EN ISO11885 \\
\hline Silver, $\mathrm{Ag}$ & $\mathrm{mg} / \mathrm{L}$ & $<0.4$ & $<0.4$ & $<0.4$ & 5 & EN ISO11885 \\
\hline
\end{tabular}

Table 6. The results of ${ }^{\circ} \mathrm{C}$ toxicity characteristic stabilized sludge on $105{ }^{\circ} \mathrm{C}$ and 200 by TCLP test method

\begin{tabular}{|l|c|c|c|c|c|c|c|}
\hline \multirow{2}{*}{ Parameter } & \multirow{2}{*}{$\begin{array}{c}\text { Measure } \\
\text { unit }\end{array}$} & $\begin{array}{c}\mathrm{R} 4 \\
(105)\end{array}$ & $\begin{array}{c}\mathrm{R} 8 \\
(105)\end{array}$ & $\begin{array}{c}\mathrm{R} 4 \\
(200)\end{array}$ & $\begin{array}{c}\mathrm{R} 8 \\
(200)\end{array}$ & $\begin{array}{c}\text { Limit } \\
\text { value [36] }\end{array}$ & $\begin{array}{c}\text { Analytical } \\
\text { testing } \\
\text { standard } \\
\text { method }\end{array}$ \\
\cline { 3 - 6 } & $\mathrm{\mu g} / \mathrm{L}$ & 3.8 & $<2.1$ & 7.2 & $<2.1$ & 5000 & EN ISO11885 \\
\hline Lead, $\mathrm{Pb}$ & $\mu \mathrm{g} / \mathrm{L}$ & 9.1 & 203.9 & 3.2 & 186.5 & 1000 & EN ISO11885 \\
\hline Cadmium, $\mathrm{Cd}$ & $\mathrm{mg} / \mathrm{L}$ & 4.7 & 9.6 & 1.2 & 20.1 & 250 & EN ISO11885 \\
\hline Zinc, $\mathrm{Zn}$ & $\mathrm{mg} / \mathrm{L}$ & 26.7 & 3.0 & 9.4 & 2.4 & 25 & EN ISO11885 \\
\hline Copper, $\mathrm{Cu}$ & $\mathrm{mg} / \mathrm{L}$ & 0.12 & 1.3 & 0.23 & 1.9 & 20 & EN ISO11885 \\
\hline Nickel, $\mathrm{Ni}$ & $\mu \mathrm{g} / \mathrm{L}$ & 26.3 & 5.6 & 5.0 & 2.7 & 5000 & EN ISO11885 \\
\hline $\begin{array}{l}\text { Chromium total, } \\
\text { Cr }\end{array}$ & $\mathrm{mg} / \mathrm{L}$ & $<0.0005$ & $<0.0005$ & $<0.0005$ & $<0.0005$ & 0.2 & VMK C.h.1 1 \\
\hline Mercury, $\mathrm{Hg}$ & $\mu \mathrm{g} / \mathrm{L}$ & 21.6 & 10.2 & $<2.1$ & $<2.1$ & 5000 & EN ISO11885 \\
\hline Arsenic, $\mathrm{As}$ & $\mu \mathrm{g} / \mathrm{L}$ & $<0.86$ & $<0.86$ & $<0.86$ & $<0.86$ & 15000 & VMK C.G.1 \\
\hline Antimony, $\mathrm{Sb}$ & $\mu \mathrm{g} / \mathrm{L}$ & 37.4 & 29.6 & 30.9 & 21.2 & 100000 & EN ISO11885 \\
\hline Barium, $\mathrm{Ba}$ & $\mu \mathrm{g} / \mathrm{L}$ & 10.0 & $<4.5$ & 7.6 & $<4.5$ & 1000 & EN ISO11885 \\
\hline Selenium, $\mathrm{Se}$ & $\mathrm{mg} / \mathrm{L}$ & $<2.3$ & $<2.3$ & $<2.3$ & 2.7 & 350 & EN ISO11885 \\
\hline Molibdenium, $\mathrm{Mo}$ & $\mathrm{mg} / \mathrm{L}$ & $<0.008$ & $<0.008$ & 0.10 & $<0.008$ & 24 & EN ISO11885 \\
\hline Vanadium, $\mathrm{V}$ & $\mathrm{mg} / \mathrm{L}$ & $<0.4$ & $<0.4$ & $<0.4$ & $<0.4$ & 5 & EN ISO11885 \\
\hline Silver, $\mathrm{Ag}$ & & & & & & \\
\hline
\end{tabular}


Based on the results presented in Table 5 and 6 it is seen that $\mathrm{Cu}$ concentration in sludge obtained by neutralization process from Robule Lake on $\mathrm{pH} 4$, marked as $\mathrm{R} 4$ (105), and stabilized on $105^{\circ} \mathrm{C}$, has the higher value than the limited value. Result. For all other samples the obtained values for concentration of $\mathrm{Pb}, \mathrm{Cd}, \mathrm{Zn}, \mathrm{Cu}, \mathrm{Ni}, \mathrm{Cr}$ tot., $\mathrm{Hg}, \mathrm{As}, \mathrm{Sb}, \mathrm{Ba}, \mathrm{Se}, \mathrm{Mo}, \mathrm{V}$ and $\mathrm{Ag}$ are highly below the limit values. In accordance with the Regulation on categories, testing and classification of waste in Republic of Serbia, this sludge has not be disposal before the prior treatment.

The value for copper concentration in TCLP extractit obtained from sludge in neutralization process of Robule AMD on $\mathrm{pH}$ 4 and stabilized on on $105{ }^{\circ} \mathrm{C}$ is higher than limit value for toxicity characteristic of waste. Taking into account the method uncertainty (uncertainty of preratation and determination), monitoring of R4 (105) sludge toxicity characteristic should be carried out in future period.

\section{Conclusions}

Acid mine drainage (AMD) is a consequence of uncontrolled oxidation of sulphide minerals, especially pyrite, which are initially exposed to the environment by intensive mining activities in Bor area.

The results of leachability test are not within the permitted limits for the disposal of nonhazardous waste to the landfill. Stabilized sludges show tendency to lower leachability of zinc and copper, but without influence on sulphate leachability.

Sludge that shows a H8-corrosiveness characteristic needs additional pretreatment stabilization/neutralization method prior temperature treatment stabilization.

The value for copper concentration in TCLP extractit obtained from sludge in neutralization process of Robule AMD on $\mathrm{pH}$
4 and stabilized on on $105{ }^{\circ} \mathrm{C}$ is higher than limit value for toxicity characteristic of waste, but this results is in area of method unceratainty. Monitoring of R4 (105) sludge toxicity characteristic should be carried out in future period.

\section{Acknowledgements}

This paper is result of Japan, Serbia mutual JICA Project in the SATREPS program:" The Project for the Research on the Integration System for Spatial Environment Analysis", funded from the donation of the Japanese Government, with the participation of Serbian funding and Project No. 37001, „The Impact of Mining Waste from RTB Bor on the Pollution of Surrounding Water Systems with the Proposal of Measures and Procedures for Reduction the Harmful Effects on Environment", funded by the Ministry of Education and Science the Republic of Serbia.

\section{References}

[1] Johnson, D. B., Hallberg, K. B. (2005) Acid mine drainage remediation options: a review. Science of the total environment, 338 (1), 3-14.

[2] Anawar, H. M. (2015) Sustainable rehabilitation of mining waste and acid mine drainage using geochemistry, mine type, mineralogy, texture, ore extraction and climate knowledge. Journal of environmental management, 158, 111-121.

[3] Egiebor, N.O., Oni, B. (2007) Acid rock drainage formation and treatment: a review. Asia-Pacific Journal of Chemical Engineering 2, 47-62.

[4] Bogdanović, G. D., Trumić, M. Ž., Stanković, V., Antić, D.V., Trumić, M. S., Milanović, Z. (2013) Mine waters from Mining \& Smelting Basin Bor - A resource for the recovery of copper or 
polluter of the environment, Recycling and Sustainable Development 6, 41-50, (In Serbian).

[5] Macingova, E., Luptakova, A. (2012) Recovery of metals from acid mine drainage. Chemical Engineering.

[6] Modabberi, S., Alizadegan, A., Mirnejad, H., Esmaeilzadeh, E. (2013) Prediction of AMD generation potential in mining waste piles, in the sarcheshmeh porphyry copper deposit, Iran. Environmental monitoring and assessment, 185 (11), 9077-9087.

[7] Ouyang, Y., Liu, Y., Zhu, R., Ge, F., Xu, T., Luo, Z., Liang, L. (2015) Pyrite oxidation inhibition by organosilane coatings for acid mine drainage control. Minerals Engineering, 72, 57-64.

[8] Blodau, C. (2006) A review of acidity generation and consumption in acidic coal mine lakes and their watersheds. Science of the total environment, 369 (1), 307-332.

[9] Chen, Y.T., Li, J.T., Chen, L.X., Hua, Z.S., Huang, L.N., Liu, J., Xu, B.B., Liao, B., Shu, W.S. (2014) Biogeochemical processes governing natural pyrite oxidation and release of acid metalliferous drainage. Environmental science \& technology, 48 (10), 5537-5545.

[10] Dimitrijević, M. D., Antonijević, M. M., Dimitrijević, V. L. (2002) Oxidation of pyrite: Consequences and significance. Hemijska industrija, 56 (7-8), 299-316, (In Serbian).

[11] Han, Y. S., Youm, S. J., Oh, C., Cho, Y. C., Ahn, J. S. (2017) Geochemical and eco-toxicological characteristics of stream water and its sediments affected by acid mine drainage. Catena, 148, 52 59.

[12] Pierre Louis, A. M., Yu, H., Shumlas, S. L., Van Aken, B., Schoonen, M. A., Strongin, D. R. (2015) Effect of phospholipid on pyrite oxidation and microbial communities under simulated acid mine drainage (AMD) conditions. Environmental science \& technology, 49 (13), 7701-7708.

[13] Plante, B., Bussière, B., Benzaazoua, M. (2012) Static tests response on 5 Canadian hard rock mine tailings with low net acid-generating potentials. Journal of Geochemical Exploration, 114, 57-69.

[14] Plante, B., Bussière, B., Benzaazoua, M. (2014) Lab to field scale effects on contaminated neutral drainage prediction from the Tio mine waste rocks. Journal of Geochemical Exploration, 137, 37-47.

[15] Akcil, A., Koldas, S. (2006) Acid Mine Drainage (AMD): causes, treatment and case studies. Journal of Cleaner Production, 14 (12), 1139-1145.

[16] Dimitrijević M.D. (2012) Acid mine drainage, Copper. 37 (1), 33-44, (In Serbian).

[17] Simate, G. S., Ndlovu, S. (2014) Acid mine drainage: Challenges and opportunities. Journal of Environmental Chemical Engineering, 2 (3), 17851803.

[18] Kefeni, K. K., Msagati, T. A., Mamba, B. B. (2017) Acid mine drainage: Prevention, treatment options, and resource recovery: A review. Journal of Cleaner Production, 151, 475-493.

[19] Kumari, S., Udayabhanu, G., Prasad, B. (2010) Studies on environmental impact of acid mine drainage generation and its treatment: an appraisal. Indian Journal of Environmental Protection, 30(11), 953967.

[20] Singer, P. C., Stumm, W. (1970) Acidic mine drainage: the rate-determining step. Science, 167 (3921), 1121-1123. 
[21] Chen, M., Lu, G., Guo, C., Yang, C., Wu, J., Huang, W., ... Dang, Z. (2015) Sulfate migration in a river affected by acid mine drainage from the Dabaoshan mining area, South China. Chemosphere, 119, 734-743.

[22] Blowes, D. W., Ptacek, C. J., Jambor, J. L., Weisener, C. G. (2003) The geochemistry of acid mine drainage. Treatise on geochemistry, 9, 612.

[23] Chen, T., Yan, B., Lei, C., Xiao, X. (2014) Pollution control and metal resource recovery for acid mine drainage. Hydrometallurgy, 147, 112119.

[24] Gray, N. F. (1998) Acid mine drainage composition and the implications for its impact on lotic systems. Water Research, 32 (7), 2122-2134.

[25] Galhardi, J. A., Bonotto, D. M. (2016) Hydrogeochemical features of surface water and groundwater contaminated with acid mine drainage (AMD) in coal mining areas: a case study in southern Brazil. Environmental Science and Pollution Research, 23 (18), 1891118927.

[26] Shim, M. J., Choi, B. Y., Lee, G., Hwang, Y. H., Yang, J. S., O'Loughlin, E. J., Kwon, M. J. (2015) Water quality changes in acid mine drainage streams in Gangneung, Korea, 10 years after treatment with limestone. Journal of Geochemical Exploration, 159, 234242.

[27] Olds, W. E., Tsang, D. C., Weber, P. A., Weisener, C. G. (2013) Nickel and zinc removal from acid mine drainage: roles of sludge surface area and neutralising agents. Journal of Mining, (2013), p. 5,

[28] Tolonen, E. T., Sarpola, A., Hu, T., Rämö, J., Lassi, U. (2014) Acid mine drainage treatment using by-products from quicklime manufacturing as neutralization chemicals. Chemosphere, 117, 419-424.

[29] McDonald, D.M., Webb, J.A., Musgrave, R.J., (2006) The effect of neutralisation method and reagent on the rate of $\mathrm{Cu}$ and $\mathrm{Zn}$ release from acid rock drainage treatment sludges. In: Proceedings of the $7^{\text {th }}$ ICARD, St. Louis, MO, USA, March, 1198-1218.

[30] Murdock, D.J., Fox, J.R.W., Bensley, J.G., (1994) Treatment of acid mine drainage by the high density sludge process. In: Proceedings of the International Land Reclamation and Mine Drainage Conference and Third International Conference on the Abatement of Acid Drainage, Pittsburgh, April, vol. 1, 241-249.

[31] Herrera, S.P., Uchiyama, H., Igarashi, T., Asakura, K., Ochi, Y., Ishizuka, F., \& Kawada, S. (2007) Acid mine drainage treatment through a two-step neutralization ferrite-formation process in northern Japan: Physical and chemical characterization of the sludge. Minerals Engineering, 20 (14), 13091314.

[32] Hakkou, R., Benzaazoua, M., (2014) Environmental challenges facing closed mine sites reclamation in Morocco, Proceedings of the Closing Workshop of the IGCP/SIDA Projects 594 and 606, Prague, Czech Republic, May 2628, 49-51

[33] Basta, N. T., McGowen, S. L. (2004) Evaluation of chemical immobilization treatments for reducing heavy metal transport in a smelter-contaminated soil. Environmental pollution, 127 (1), 73-82.

[34] EN 12457-2 (Characterization of waste - Leaching - Compliance test for leaching of granular waste materials and sludges - Part 2: One stage batch test at a liquid-solid ratio of $101 / \mathrm{kg}$ for 
materials with a high content solids and particle size of less than $4 \mathrm{~mm}$ (with decreasing particle size, or without decreasing), 2008.

[35] EPA Method 1311: Toxicity Characteristic Leaching Procedure, 1992.

[36] Regulation on categories, testing and classification of waste (Office Gazete RS 56/2010.

[37] Bogdanović, G. D., Stanković, V. D., Trumić, M. S., Antić, D. V., Trumić, M. Ž. (2016) Leaching of low-grade copper ores: A case study for Kraku Bugaresku-Cementacija deposits (Eastern Serbia). Journal of Mining and Metallurgy A: Mining, 52 (1), 45-56.

[38] Stanojlović, R. D., Sokolović, J. M., Milosević, N. (2014) Integrated environmental protection and waste minimization in the area of Copper mine Bor, Serbia. Environmental Engineering \& Management Journal (EEMJ), 13 (4), 791-804.

[39] Stevanović, Z., Obradović, L., Marković, R., Jonović, R., Avramović, L., Bugarin, M., Stevanovic, J. (2013) Mine Waste Water Management in the Bor Municipality in Order to Protect the Bor River Water. In Waste WaterTreatment Technologies and Recent Analytical Developments. InTech.

[40] Gardić, V. R., Petrović, J. V., Đurđevac-Ignjatovic, L. V., Kolaković, S. R., Vujović, S. R. (2015) Impact assessment of mine drainage water and municipal wastewater on the surface water near the city of Bor. Chemical Industry, 69 (2), 165-174, (In Serbian).

[41] Korać M., Kamberović Ž. (2007) Characterization of wastewater streams from Bor site, Metallurgical \& Materials Engineering 13 (1), 41-51.

[42] Beškoski V.P., Papić P., Dragišić V., Matić V., Vrvić M.M. (2009) Long term studies on the impact of thionic bacteria on the global pollution of waters with toxic ions, Advaced Materials Research 71-73, 105-108.

[43] Ishiyama, D., Kawaraya, H., Sato, H., Obradovic, L., Blagojević, B., Petrovic, J., ... Takasaki, Y. (2012) Geochemical Characteristics of Mine Drainage Water and River Water in the Bor Mining Area, Serbia: Results of Study in 2011, 41-49. 